\title{
Reading Literature: An Ethical Gesture in the Postmodern Context?
}

\author{
Angela Locatelli \\ Università degli studi di Bergamo
}

"The essence of great art is tension without bloodshed."

(Morrison 2005:717)

"The norm of art is to be found in its utility for the treatment of the affections of the soul."

(Badiou 2005:4)

\begin{abstract}
After the so called Ethical Turn in literary theory ethics is still a major issue in literary studies. European Continental philosophy has traditionally been in close touch with ethical issues. Not surprisingly then, it was the influence of French philosophy that, from the Eighties onward, began to put back the ethical in British academic discourse. One of the interesting paradoxes of post-modernity is the fact that, while it promotes an attitude of scepticism, oriented towards a strong suspicion of strong ideologies, it is also an attempt to promote emancipative activities (demonstrated in the Canon Debate, PostColonial Studies, Trauma Studies, and a broad Ethical Turn in different sectors of the humanities). This contribution wishes to investigate the issue of ethics and literature in the postmodern context, with reference to contemporary philosophy and literary theory and aims to propose that Postmodern culture still needs complex literature, and (the promotion of) appropriate hermeneutic skills to deal with it.

Key words: postmodern culture, ethics and politics, representation, dialogic reading of literature.

\section{Introduction}

Values are not a natural given, but they are created, proposed, negotiated and disseminated in culture, and it is crucially important to understand how this is effected in various representational processes. As we address this ancient issue, which runs through the history of philosophy and literature from Aristotle to Alain Badiou, we recognize that the realms of ethics, politics and representation have always been, and still are, mutually implicated and responsive to each other. Representation is never innocent, or objectively neutral, especially when it claims to be so. Specific mechanisms are at work in representation, and they are both the expression and vehicle of different values and value judgments. After the so called Ethical Turn in literary theory at the beginning of our millennium (Davis and Womack 2001) ethics is still a major issue in literary studies. This contribution wishes to investigate it with special focus on its relevance to global post-modernity and contemporary culture.
\end{abstract}




\section{The Paradoxical Ethics of the Postmodern}

The question of defining the postmodern in cultural, philosophical, and literary terms is fraught with intricacies and contradictions. When this question is combined with the problem of ethics and representation such contradictions multiply, because postmodernism is the expression of a cultural sensibility which involves both the political and the a-political, the writer's ethical commitment and a sceptical attitude in relation to (traditional) values, a traditional referential view of history and a new narratological, and even fictional, conception of it.

Postmodernism claims a constructivist and an anti-foundational epistemology, it inaugurates the so-called, and highly controversial, post-human paradigm, and features a de-centering of the traditional subject of liberal humanism. Because of all this, it is often deemed radically un-ethical. And yet, I believe that the question of ethics is not absent from the cultural stakes of post-modernity. The ethical concerns of postmodern times and culture are evident in a range of phenomena that can hardly be defined as homogeneous, but that share an indisputably ethical dimension. Among these phenomena I wish to recall: the Canon debate in literary studies (cf. Alberti 1995, Lauter 1995, Locatelli 2004), the rise of Feminist, Postcolonial, and Trauma Studies, and the already mentioned Ethical Turn in literary theory.

Writers and artists as well as literary and cultural critics have recently contributed to the development of a specific ethical awareness. Some of their views, for example Pier Paolo Pasolini's prophetic and relentless critique of secular consumerism (cf. Pasolini 1991 and 2008), Fredric Jameson's critique of "the cultural logic of late capitalism" (Jameson 1998), Zygmund Bauman's analysis of "liquid modernity" (Bauman 2000, and 2007) and the reflections on otherness spawned by the philosophy of Emmanuel Lévinas (cf. Lévinas 1961,1974, 1981, and 1991) have all become central in the way ethics is articulated in our times in literary culture(s). I obviously cannot deal at length with these debates in just a few pages, but these artists, theorists and philosophers are undoubtedly to be mentioned because of their ongoing relevance in contemporary questions of ethics and culture. Postmodern culture is complex, nuanced, and even paradoxical. Its ethics claims to be non-essentialist, non-foundational, and negotiable, rather than normative. However, in its flaunted uncertainty it displays attitudes which may seem grounded on a readiness to embrace and mix elements from diverse and diverging normative and established doctrines and protocols. A certain ambivalence towards ethics and a concomitant distancing from the political can also be perceived in large areas of postmodern globalized discourses (cf. Lecercle 2010).

The relationship between ethics and politics has always been, and is still a complex one, clearly beyond the scope of this paper, which is primarily concerned with literature and its academic study as part of culture. Focussing on this circumscribed critical perspective, I will first of all come to terms with the recent poststructuralist neglect of ethics, which is evident in British academic discourses since the Seventies of the $20^{\text {th }}$ Century. Andrew Gibson has attributed to positivism and to the "politics of English" (Gibson 1999 ) in the early 1970s this general academic disregard and/or suspicion of ethics. In Postmodernity, ethics and the novel. From Leavis to Levinas Gibson shows that speak- 
ing of value has recently been, and for quite a long time, a taboo in literary studies in Britain. In the aftermath of F.R. Leavis' pronouncements on The Great Tradition, the very term value has become suspect. A general ostracism of discourses about value has produced a cultural void on questions of ethics in the past three or four decades, for which literary theory has sometimes been blamed, undeservedly, in my opinion. In fact, from a continental (as opposed to British) perspective it seems indeed strange that radical politics in British academy would construe an opposition between the ethical and the political, but this becomes perhaps more understandable (albeit still philosophically questionable and politically problematic), if one considers that the Leavisian brand of self-proclaimed ethical criticism was ideologically conservative and lacked self-reflexive questioning. Distance from questions of ethics in Britain may also have come from the traditional Anglo-Saxon protocols of philosophy, which favors an analytical and logical approach to the discipline, rather than a generalist and literary approach, explicitly harboring ethical questions. As Jean-Jacques Lecercle has suggested in his recent book Badiou and Deleuze Read Literature: "continental philosophy likes to address the concerns of the general public: where the analytic philosopher is a shy and retiring creature, the continental philosopher is a man, or woman, of the world - his or her voice is heard on the agora, in the media, thus gaining a form of recognition" (Lecercle 2010:13). Continental philosophers such as Habermas, Foucault, Cacciari, Vattimo, Badiou, Derrida and Deleuze have often voiced ethical and political issues, and have reached wide and widely different audiences in terms of taste, education, and profession. European Continental philosophy has been a formative matrix for sociologist, anthropologists and psychoanalysts, and has thus been in close touch with ethical issues, both inside and outside the academy. Not surprisingly then, it was the influence of French philosophy that, from the Eighties onward, began put back the ethical in British academic discourse. This happened in a second phase of poststructuralism, after the anesthetized earlier phase of a radical linguistic turn (heavily condemned by philosophers like Deleuze and Badiou). Among the literary theorists who have forcefully contributed to a return to the ethical in academic debate in Britain I wish to recall: Andrew Gibson (Gibson 1996), Robert Eaglestone (Eaglestone 1997 and 2003), Derek Attridge (Attridge 1999 and 2004). The developments in feminist, queer, postcolonial studies can also be seen as important forms of ethical criticism, with an obvious and relevant ideological difference from the previous Leavisian conservative approach, while at the same time clearly distant from Marxist political critique.

One of the interesting paradoxes of postmodernity is therefore the fact that, while it promotes a general attitude of scepticism and relativism, oriented towards a strong suspicion of traditional strong ideologies, it is also an attempt to promote an Ethical Turn in the humanities. In the U.S. many representatives of both New Historicism and Deconstruction have been engaged in the Canon debate (itself a relevant ethical issue), and, following the affaire deMan they have engaged in the promotion of Trauma studies (cf. Caruth 1995, Whitehead 2004 and Onega and Ganteau 2011), variously responding to the ethical urge of attempting to represent the "irrepresentable" (Harman 1996). Moreover, social and literary theorists in Britain and North America have turned to 
Emmanuel Lévinas (cf. Lévinas 1981 and 1991) in order to defend a view of ethics in terms of an encounter with the Other. On the other hand, the Other has also come to be interpreted (in Anthropology and Cultural Studies), as the oppressed subject of social minorities: i.e. the alien, the woman, the queer, the (post?)-colonial ${ }^{1}$ subject, the migrant. This is a relevant articulation of the concept of otherness at a moment in which, with the advent of mass migrations, the question of natural rights and civil rights is under close scrutiny and re-articulation. The meanings of human rights, or natural rights have to be re-defined, within a rethinking of political subjectivity in inclusive, rather than excluding terms. Etienne Balibar and Alain Badiou have fruitfully combined the ethical and the political while investigating this particular issue in Politics and the Other Scene (2011) and in L'éthique. Essai sur la conscience du mal (2011). An increasing number of social theorists, and several writers and poets with them, have also been voicing the idea that political rights have necessarily to be expanded beyond the narrow confines of nation, and even of ethnic identity, in order to do justice to a universal concept of the human. This is part of Alain Badiou's polemical argument in his seminal study of St Paul (Badiou 2003).

In the tradition of French Marxist critique (Alain Badiou and Jean-Jacques Lecercle) the resurgence of interest in ethics in literary studies has also been depicted as ambiguously deflecting attention from a political focus, and immediate political action. Which does not in the least deny the political significance of literature, which is, on the contrary, upheld in the works of the same Badiou (cf. Badiou 2006) and Lecercle (cf. Lecercle 2006), and of other philosophers, for example Jacques Rancière (cf. Rancière 2004 and 2007) and Guilliaume Le Blanc (cf. Le Blanc 2007). After these philosophers, and against the scepticism of some towards literary theory (accused of being a predicament that remains distant from daily concerns), I believe that the literary experience and literary studies can valuably contribute to the ethical and political debate in postmodern culture, and I will devote to this argument the pages that follow.

\section{The Literary Ethical Dimension: Reading (with) the Other}

In the complex context of post-modernity outlined this far, the debate on the social impact and role of literature has been lively, swinging from elation to despair, and presenting all sorts of in-between positions in the past thirty years. In 1987 Gerald Graff lamented the fact that: "high literary culture" is "increasingly marginal to the commercial and corporate interests dominating modern life" (Graff 1987:12), a complaint that is still repeatedly voiced in academia. Almost ten years later Martha Nussbaum strongly endorsed the vital social role of literature, by suggesting that it can move us beyond the abstractions of both ethics and the social sciences, because it makes us "capable of entering imaginatively into the lives of distant others" (Nussbaum 1995:xvi).

The Italian writer Italo Calvino has explored the issue of literature and politics and has suggested that literature is at risk when it finds itself in two apparently opposite situations: either an excess of attention or a lack of attention on the part of politics and the public: "When politicians and politically minded people pay too much attention to literature, it is a bad sign - a bad sign mostly for literature, because it is then that literature is in most 
danger. But it is also a bad sign when they don't want to hear the word mentioned, and this happens as much to the most traditionally obtuse bourgeois politicians as to the most ideological revolutionaries. This is a bad sign mostly for $t^{2} m^{2}$, because they are showing themselves afraid of any use of language that calls the certitude of their own language into question" (Calvino 1986: 93). This last sentence seems extremely relevant to our concerns because I believe that it implies, among other aspects, that the language of literature does not, and should not coincide with the language of politics tout court, while at the same time being acutely mindful of politics. If a work is written in the language of politics, it ceases to be literature ${ }^{3}$, but becomes sociology and/or social psychology, or a text of political argumentation, or even indoctrination and propaganda. We have unfortunately witnessed reductive forms of such literary discourse in some romans $\grave{a}$ these, and more recently in politically correct novels, which mostly persuade the already persuaded, but fail to engage the reader at the complex level of controversy and judgment to which literature is intrinsically conducive. But it is precisely at the level of questioning and judgment that literature becomes most ethical. It is at this level that it can provoke debate, expose bias and provide the ground for its rejection. In fact, only literature among the human sciences can reach a specific epistemic complexity and ethical significance, precisely thanks to its figurality and special narrativity (i.e. the thanks to its linguistic sophistication, and to its various modes of narration which greatly differ from other ways of telling in ordinary discourse or in other disciplines). The ethical dimension of literature depends on its unique style (provided we reject a view of style as embellishment and ornament and see it as the language proper to an epistemic and aesthetic position). Thanks to its intrinsic plurality of voices (Bahktin $d o c e t)^{4}$, its ambiguity (Empson $\left.d o c e t\right)^{5}$, and its linguistic richness literature transcend the plain statement, which is the main feature of discourses of power, and indeed of most of the contemporary human sciences (with the exception of philosophy, especially after Derrida and Deleuze). When it is faithful to its own immanence, and its criticality, literature literally "speaks a different language" (cf. Calvino 1986). In this sense I completely agree with Calvino when he writes that: "Literature is like an ear that can hear things beyond the understanding of the language of politics, it is like an eye that can see beyond the color spectrum perceived by politics" (Calvino 1986:98).

The ear and eye provided by literature are not innate faculties. They are abilities to be acquired with the critical practice of dialogic reading (cf. Locatelli 2003), which amounts to the activity of an attentive reader, of an open minded and a careful listener, of someone who is patiently seeking information on historical contexts and cultures related to the text, and who is sensitive to the nuances of language and who is also ready to be surprised and even destabilised in his/her commonsensical attitudes by the text. The dialogic reader is not eager to jump to conclusions in order to confirm his/her received doxa on human relations, and thus to make of texts the pretext for his/her own motives, and a confirmation of what he/she already holds as valuable. Readers must learn hermeneutical strategies that do not reject the careful minutiae of traditional close reading, and the concomitant implications of respecting the text, but they should not stop there. Going beyond means that interpretation needs to be shared, so that it may teach readers to step outside their own positions, and look at themselves from another one, in 
order to perceive their own location as it is perceived by (distant) others. This change of perspective involves un-hinging the reader's expectations, exposing his/her assumptions, and expressing his/her distances from other assumptions, while promoting the interaction of different points of view. This means that the reader (whose role is as crucial as that of the text in the construction of meaning) should come to terms with the presence of more than one's own interpretive community, and thus more than just one form of hermeneutic validation. Ignorance can thrive in a society where a rule-based and univocal view of the world holds the stage. Not knowing other possibilities, scenarios, world pictures, undoubtedly leads to the arrogance of self-righteousness, and to the absolutism of selfinterested norms. Pushed to its limit, this attitude obviously makes the encounter with otherness, utterly impossible. But the experience of literature is a genuine encounter the other, which starts, as I have suggested, with the opening of one's ears and eyes, and includes the experience of wonder and discovery, the re-appraisal of norms and the shaping of novel attitudes. Literature is able to promote complex identifications and dis-identifications with different subjects and it thus promotes judgement, through both the intellect and the emotions. But when literature is taken to be a mere ornament, a means of evasion or of political indoctrination, rather than a means of deepening human understanding, literature betrays its own epistemic reality and primary social function, as well.

Derek Attridge's seminal notions of readerly hospitality defines the attitude of respect that is implicit in any dialogic reading: "The always dominant mode of mechanical reading can be modified or interrupted by a somewhat different relation to the work. Not all works will have something to offer to a reader's openness to alterity, of course, but when one does, mechanical and instrumental interpretation is complicated by what we may term readerly hospitality, a readiness to have one's purposes reshaped by the work to which one is responding" (Attridge 2004:80). Respect allows readers to move beyond mechanical reading, it starts from an unbiased and keen attention to the particular, an attitude that has recently been defended as ethical by Herbert Grabes in his examination of the centrality of aesthesis in Aristotle Nicomachean Ethics (Grabes 2009). Last but not least, a dialogic reading of literature is respectful of the Other's response(s) and ceaselessly moves towards the construction of shared meanings. Sharing the construction of meanings is a difficult task, but one to be pursued since it puts a limit to unbridled relativism and uncritical dogmatism, as well as rejecting the idea that anything will do in interpretation, including the whims of a capricious or tendentious reader.

Adding to this perspective on the position of the reader in ethical terms, I will propose that the ethical dimension of literature is closely related to the following interpretative and critical gestures, which can all be implemented in the postmodern pluralistic cultural context:

1. Reading texts to grasp their structures, features and functions. This is an exercise in patience, rigour, and even self-denial (resisting the temptation of construing the text in one's own image).

2. Finding and explaining the reasons for one's interpretative conclusions. It is a Socratic exercise in self-awareness. 
3. Reading texts to understand the workings of language.

This is also an exercise in self-knowledge, since language is at the core of human relations, of subjectivities and interlocution (Lecercle 2006).

4. Reading texts to discover their relationship to forms of power.

It is a premise to any acceptable critique of ideology. It is also a metaethical exercise evaluating "values".

This is a relevant task of literary studies, and promotes ethically valuable strategies of emancipation from error and oppression.

5. Reading to manage trauma.

It is both a therapeutic and ethical gesture, because ultimately a strategy of containment of violence and of human flourishing (eudaimonia).

All of these ways of reading literature are forms of dialogue and practices of pluralism, and from them emerges the ethically transformative power of the reading itself, which post-modernity urgently needs to remain human. Rather than settling with the mainstream reductive market view of literature as escapism and entertainment, or as a straightforward politically correct message, we should, as academics, promote the enjoyment of complex literature, to voice alternatives to the predictable and mechanical relationships and subjectivities that are promoted by techno-corporate interests (cf. Pasolini 1991 and 2008 and Bauman 2007). In fact, the reading of literature is a therapeutic strategy against blind compliance to both fundamentalisms and the imperatives of financial and techno-bureaucratic protocols. In the postmodern context, the dialogic reading of literature is of primary social relevance: what is at stake is the survival of the imagination (and sanity). The imaginative, emotional and empathetic dimensions of literature make it still epistemologically unique, ethical and socially valuable. Literature goes hand in hand with our readiness to be surprised and to be challenged, to be emotionally and cognitively stimulated and enriched. This is why postmodern culture needs complex literature, and (the promotion of) appropriate hermeneutic skills to deal with it. This is an empowering and reparative gesture, once literature is seen as the "the Ecology of Wonderland" (Locatelli 2007).

\section{Notes:}

1. The question mark after the "post" preceding "colonial" is a legitimate expression of doubt on the politics of global Neoliberalism and its forms of new financial and commercial colonialisms, as well as, to some extent, on the very discipline of "post-colonial studies" in the context of a weakening Anglo-American supremacy.

2. Emphasis in the original

3. I am using the term "literature" in the restricted sense of the literary classics or canonical works, not in the broad sense of any written text.

4. Cf. Bakhtin 1981 and 1984. The Italian philosopher Augusto Ponzio has brilliantly argued in favour of "a surprising analogy between Lévinas notion of "exteriority" and Bakhtin's "extra-locality" ("vnenachodimost”). Cf. Ponzio 1997.

5. Cf. Empson 1966. 


\section{References:}

1. Alberti J. (1995) The Canon in the Classroom: The Pedagogical Implications of Canon Revision in American Literature. New York: Garland Pub.

2. Attridge, D. (1999) Innovation, Literature Ethics: Reading the Other. // PMLA, Vol. 114 , N. 1 pp.20-31.

3. Attridge, D. (2004) The Singularity of Literature. London and New York: Routledge.

4. Badiou, A. (2003) Saint Paul: The Foundation of Universalism. / Tr. by R. Brassier. Stanford, Calif:: Stanford University Press.

5. Badiou, A. (2005) Handbook of Inaesthetics. / Tr. by A. Toscano. Stanford Calif: Stanford University Press.

6. Badiou, A. (2011) L'étique. Essai sur la conscience du mal. Caen: Nous.

7. Bakhtin, M. (1981) The Dialogic Imagination. / Tr. by C. Emerson and M. Holquist. Austin, Texas.

8. Bakhtin, M. (1984) Problems of Dostoevsky's Poetics. / Tr. by C. Emerson. Minneapolis: University of Minnesota Press.

9. Balibar, E. (2002) Politics and the Other Scene. New York: Verso.

10. Bauman, Z. (2000) Liquid Modernity. Cambridge: Polity Press.

11. Bauman, Z. (2007) Consuming Life. Cambridge: Polity Press.

12. Calvino, I. (1986) Right and Wrong Political Uses of Literature. // The Uses of Literature. / Ed. by I. Calvino. / Tr. By P. Creagh. San Diego, New York and London: Harcourt Brace Jovanovich.

13. Caruth C. (ed.) (1995) Trauma: Explorations in Memory. Baltimore, MD and London: Johns Hopkins University Press.

14. Davis, T.F. and Womack, K. (2001) Mapping the Ethical Turn: A Reader in Ethics, Culture, and Literary Theory. Charlottesville: University of Virginia Press.

15. Eaglestone, R. (1997) Ethical Criticism: Reading after Lévinas. Edinburgh: Edinburgh University Press.

16. Eagleston R. (ed.) (2003) European Journal of English Studies, Ethics and Literature. Vol. VII n.3.

17. Empson, W. (1966) Seven Types of Ambiguity. New York: New Directions.

18. Gibson, A. (1996) Towards a Postmodern Theory of Narrative. Edinburgh: Edinburgh University Press.

19. Gibson, A. (1999) Postmodernity, Ethics and the Novel. From Leavis to Lévinas. London and New York: Routledge.

20. Grabes, H. (2009) What Exactly is the Case? Ethics, Aesthetics, and Aisthesis. // Values in Literature and the Value of Literature: Literature as a Medium for Representing, Disseminating and Constructing Norms and Values. / Ed. by S. Baumbach, H. Grabes and A. Nünning. Trier: Wissenschaftlicher Verlag Trier, pp.43-51.

21. Graff, G. (1987) Professing Literature. An Institutional History. Chicago and London: University of Chicago Press.

22. Guillory J. (1993) Cultural Capital: The Problem of Literary Canon Formation, Chicago: University of Chicago Press. 
23. Hartman, G.H. (1996) The Longest Shadow: In the Aftermath of the Holocaust, Bloomington IN, Indiana University Press.

24. Jameson, F. (1991) Postmodernism, Or the Cultural Logic of Late Capitalism. Durham: Duke University Press.

25. Jameson, F. (1998) The Cultural Turn: Selected Writings on the Postmodern, 19831998. London-New York: Verso.

26. Lauter, P (1991) Canons and Contexts. New York: Oxford U.P.

27. Le Blanc, G. (2007) Vies ordinaires, vies precaires, Paris: Seuil.

28. Lecercle, J.J. (2006) A Marxist Philosophy of Language. Leiden: Brill.

29. Lecercle, J.J. (2010) Return to the Political. // PMLA Vol 125 n.4. New York: The Modern Language Association of America.

30. Lecercle, J.J. (2010) Badiou and Deleuze Read Literature. Edinburgh: Edinburgh University Press.

31. Lévinas, E. (1981) Otherwise than Being: or, Beyond Essence. / Tr. by A. Lingis. The Hague: Martinus Nijhoff.

32. Lévinas, E. (1991) Totality and Infinity: An Essay on Exteriority. / Tr. A. Lingis, London: Kluwer Academic Publishers.

33. Locatelli, A. (2003) Literature: Teaching Meets "Theory”. // Textus, Vol. XVI n.1, pp. $17-26$.

34. Locatelli, A. (2004) Literariness, Consensus, or 'Something Else'. // Tropismes N 12. Whither Theory? Où va la théorie? Université Paris X Nanterre, Centre de Recherches Anglo-Americaines: Paris, pp.173-188.

35. Locatelli, A. (2007) The Ecology of Wonderland: Textual, Critical and Institutional Perspectives in Literature. // Literary Landscapes, Landscapes in Literature / Ed. by M. Bottalico, M.T. Chialant, E.Rao. Roma: Carocci Editore, pp.46-53.

36. Morrison, T. (2005) Guest Colum: Roundtable on the Future of the Humanities in a Fragmented World. // PMLA / Ed. by Toni Morrison, Gayatri Chakravorty Spivak and Ngahuia Te Awekotuku. Vol.120, n.3, pp.715-723, p.717. New York: Modern Language Association of America.

37. Nussbaum, M.C. (1995) Poetic Justice. The Literary Imagination and Public Life. Boston: Beacon Press.

38. Onega S. and Ganteau J.-M. (eds.) (2011) Ethics and Trauma in Contemporary British Fiction, Amsterdam and New York: Rodopi.

39. Pasolini, P. P. (1991) Lettere luterane. Roma: L’Unità/Einaudi.

40. Pasolini, P. P. (2008) Scritti corsari. Milano: Garzanti.

41. Ponzio, A. (1997) The relation of Alterity in Bachtin, Blanchot, Lévinas // Russian Literature, RUSLIT Vol. XLI n. III, (Special Issue Italian Contributions to the International Bachtin Dialogue 1981-1986), pp.315-331.

42. Rancière, J. (2004) The Politics of Aesthetics. London: Continuum.

43. Rancière, J. (2007) Politique de la littérature. Paris: Galilée.

44. Whitehead, A. (2004) Trauma Fiction. Edinburgh: Edinburgh University Press. 


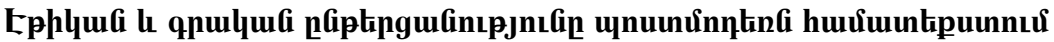

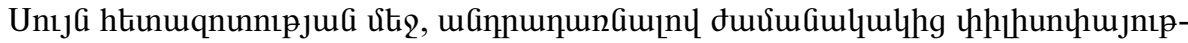

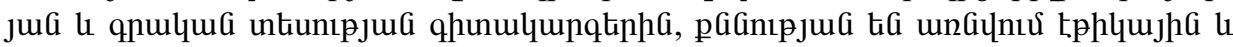

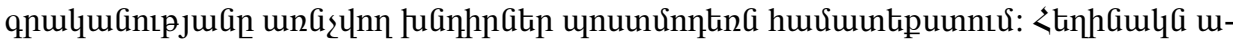

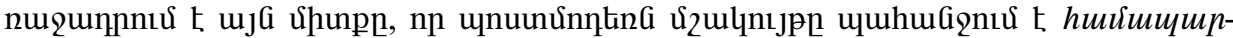

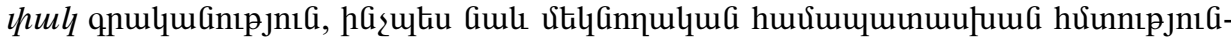

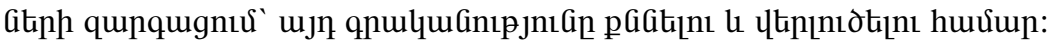

\section{Чтение литературы: этическиий жест в постмодернистском контексте?}

Целью данного исследования является изучение вопроса этики и литературы в постмодернистском контексте, со ссылкой на философию и теорию литературы. Автор выдвигает идею о том, что для изучния постмодернистской культуры необходима в комплексная литература, а также в соответствующие герменевтические навыки. 